\title{
STUDYING THE CONTRIBUTION OF SOME AGRONOMIC FACTORS TO COTTON YIELD VARIATION
}

\author{
Samir K. A. Ismail; Mohamed D.H. Dewdar and Farok M. Ismail \\ Agronomy Dept., Fac. Agric., Fayoum Univ.
}

\begin{abstract}
Two experiments were carried out at the Farm of the Faculty of Agriculture, El Fayoum University, in the summer seasons of 2005 and 2006 in a split-split plot design with three replicates, to investigate the contribution of three sowing dates $\left(25^{\text {th }}\right.$ Feb., $18^{\text {th }}$ March and $8^{\text {th }}$ April), three rates of nitrogen fertilizer (50, 70 and 90 $\mathrm{kg} \mathrm{N} /$ fed.) and three different populations of plant $(46.666,70.000$ and 93.333 plants/fed.) to cotton yield variation. The obtained results indicated that the studied plant characters were significantly affected by the variable of sowing dates. Delaying sowing to $8^{\text {th }}$ April significantly decreased number of fruiting branches/plant, number of open bolls/plant, boll weight, seed cotton yield per plant and per fed. This trend of the previous results was manifested in both seasons. Adding $90 \mathrm{~kg} \mathrm{~N} / \mathrm{fed}$. showed the highest values of number of open bolls/plant, boll weight, seed cotton yield per plant and per fed, while, lint percentage, seed index and lint index, were not significantly affected by nitrogen fertilizer rates. Plant density of 46.666 plants/fed. showed significant increment in number of fruiting branches/plant, number of open bolls/plant, boll weight, seed cotton yield per plant and lint percentage traits ,while, plant density of 93.333 plants/fed. resulted in the highest values of plant height and seed cotton yield/fed. On the other hand, seed index and lint index were not significantly affected by plant density. Yield analysis for the highest seed cotton yield obtained from the combined treatment of $\mathrm{D} \times \mathrm{N} \times \mathrm{P}$ indicted that number of fruiting branches, boll weight and number of open bolls were the major sources accounting for the variation in seed cotton yield.
\end{abstract}

Key words: Goseypium barbadanse; sowing dates; nitrogen feitilizer levels ; plant density; Cotton; Yield variation.

\section{NTRODUCTION}

Egyptian cotton (Gossypium barbadanse L.) is considered as one of the most important crops in agriculture map, regardless of the production drop that has been occurred in the last few years. It is well known that the reduction in cotton yield is mainly ascribed to the improper application of cultural practices, such as late sowing, excessive or insufficient nitrogen fertilization and unsuitable plant density which would singly or altogether affect cotton productivity. The application of the proper level from each of the aforementioned cultural practices would undoubtedly have a significant positive impact on cotton yield and quality. In the meantime, successful cotton production requires also timely application of such cultural practices.

As for the effet of sowing date on cotton plant, Abou El-Zahab et al. (2000) showed that cotton yields and only one of its yield components variable viz: number of open bolls per plant expressed significant variation in the favor of the early sowing dates viz: $15^{\text {th }}$ March and $1^{\text {st }}$ April. However,

Fayoum J. Agric. Res. \& Dev., Vol.22, No.1, January, 2008 
there was significant reduction in cotton productivity and its main yield component, i.e. number of bolls per plant for sowing after $15^{\text {th }}$ April, with lower yield for plants sown at the first of May. Ali and El-Sayed (2001a and 2001b) showed that early sowing on the last week of March led to an increment in seed index and lint percentage characters. They declared that this result could be ascribed the fact that early sowing allows longer growing season and gave available time to develop a complete boll load with mature lint and heavier seeds. Saleh et al. (2004) and El-Sayed and El-Menshawi (2005a) found that increasing number of open bolls per plant, boll weight, seed cotton yield per plant and per feddan occurred with early sowing on the last week of March. Concerning nitrogen fertilizer dose, Hamissa et al. (2000), Sadik et al. (2002), Ali (2002), El-Shazly and El-Masri (2003) reported that adding the low N-level $(30 \mathrm{~kg} / \mathrm{fed}$.) and medium $\mathrm{N}$-level $(60 \mathrm{~kg}$ $\mathrm{N} / \mathrm{fed}$.) showed insignificantly decrease in seed index as compared with the high nitrogen fertilizer level (90 kg N/fed.).

Saleh et al. (2004) showed that lint percentage, seed index and lint index were increased with increasing nitrogen fertilizer levels from 30 up to $60 \mathrm{~kg}$ N/fed. While, El-Hindi et al. (2006) indicated that number of open bolls per plant, boll weight, seed cotton yield per plant and per feddan were increased by increasing N-levels from $40 \mathrm{~kg}$ up to $80 \mathrm{~kg}$ and from $30 \mathrm{~kg}$ up to $90 \mathrm{~kg}$ N/fed. El-Shazly and Darwish (2001) showed that the application of $30 \mathrm{~kg}$ $\mathrm{N} /$ fed. significantly increased number of open bolls/plant, seed cotton yield per plant and per feddan. While, application of 45 or $60 \mathrm{~kg} \mathrm{~N} / \mathrm{fed}$., gave insignificant increase in seed cotton yield/fed. However, in Upland cotton (Gossypium hirsutum L.) Fritschi et al. (2003) indicated that application of optimal N-rates has been reported to benefit cotton yield by producing larger bolls at a greater number of fruiting sites.

The distribution of plants which is governed by spacing between hills and rows resulting number of plants per unit area, is one of the most important factors in determining seed cotton yield and its attributes .In this regard, in Upland cotton varieties (Gossypium hirsutum L.), Vacek et al. (2000) and James et al. (2004) found that increasing plant density from 134000 up to 224000 plants per hectare, decreased boll weight, number of open bolls per plant and seed cotton yield per plant.While, El-Hindi et al. (2006) in Egypt stated that increasing plant density from 56.000 up to 93.333 plant per fed. led to decreasing number of open bolls per plant, boll weight and seed cotton yield per plant. However, Abdel-Aal et al. (2000), El-Shahawy et al. (2000) and El-Sayed and El-Menshawi (2005a) pointed out that plant density did not show any significant effect on boll weight and seed cotton yield per feddan .Concerning the association between plant characters, Badr et al. (2001) in Egyptian cotton varieties, found positive significant correlation between seed cotton yield and each of boll weight, seed index, lint index and lint percentage. Hassan and Abdel-Aziz (2004) in their study of cotton yield analysis, indicated that boll weight, number of open bolls per plant and seed index were significantly contributing to the variation in seed cotton yield. They added that the total contribution of these characters to the variation in seed cotton yield was $91.69 \%$. Nevertheless, the main objectives of the present study are to find out the best treatment combination involving the three cultural practices considered in this study, which would promote cotton yield and its components, and to determine the yield component variables account for most of the variation in yield.

Fayoum J. Agric. Res. \& Dev., Vol.22, No.1, January, 2008 

MATERIAL AND METHODS:

The present study was carried out at the experimental farm of the Faculty of Agriculture, El-Fayoum Univ., during the two growing seasons of 2005 and 2006 to study the contribution of sowing dates, nitrogen fertilizer levels and plant density to cotton yield variation.

Layout of the experiments:

The three variables investigated in this study were a) three sowing dates i.e. early date on the $25^{\text {th }}$ of Feb., medium date on the $18^{\text {th }}$ of March and late date on the $8^{\text {th }}$ of April, b) three nitrogen levels i.e. 50,70 and $90 \mathrm{Kg} \mathrm{N} / \mathrm{fed}$. were applied and c) three plant populations of 46. 666, 70.000 and 93.333 plants per fed. were used. In each experiment, treatments were arranged in a split-split plot design with three replications where sowing dates were alloted to the main plots, nitrogen levels to the sub-plots and plant density were arranged in the sub-sub plots. The sub-sub plot size was $3 \times 7 \mathrm{~m}=21 \mathrm{~m}^{2}$ and contained 5 rows each is of $60 \mathrm{~cm}$ wide and $7 \mathrm{~m}$ long, The cotton variety used in this study was Giza 90.

The plant density was controlled by distance between hills at sowing time and seedling thinning. Seed were sown at 15, 20 and $30 \mathrm{~cm}$ apart and thinned to two plants per hill 6 weeks after planting. Nitrogen fertilizer was applied in the form of ammonium nitrate (33.5\%). Each applied rate was partitioned into two equal doses, added before the second and third irrigations. All the cultural practices were applied in the same manner as usually done in the ordinary cotton fields, except for the variables under study.

Characters, sampling and measurements:

At harvesting, the following traits were measured on 5 consecutive plants chosen at random from the fifth row of each sub-sub plot in three replicates;1-Plant height,2-Number of fruiting branches per plant, 3- Number of open bolls/plant, 4- Boll weight, 5- Seed cotton yield/plant in gram, 6- Seed cotton yield in terms of Kentar/fed, 7- Lint percentage, 8- Seed index and 9Lint Index.

Statistical analysis

The data obtained were subjected to statistical analysis according to the procedures outlined by Snedecor and Cochran (1981). Mean values of the studied characters were compared by L.S.D. test at $5 \%$ and $1 \%$ levels of significance. Simple correlation coefficient between seed yield (Y) and the studied characters and between the characters with each others were calculated. Also, the stepwise multiple regression analysis was carried out according to the procedures outlined by Draper and Smith (1966) to determine the variables which would account for the most of variation in yield. The relative contribution of each variable was calculated as coefficient of determination. Path coefficient analysis was used to identify the different characters which affect the independent character directly as well as indirectly.

\section{RESULTS AND DISCSSION}

\section{1-A-Sowing date effect:}

Data presented in Tables 1 and 2 indicated that the three sowing dates used in the study significantly affected growth and yield characters, where the early sowing date of (25 Feb.) induced significant increase in number of fruiting branches, plant height, number of open bolls, boll weight, seed cotton yield per plant and per feddan, seed and lint indices, as compared to medium

Fayoum J. Agric. Res. \& Dev., Vol.22, No.1, January, 2008 
and late sowing dates. This trend was manifested in both seasons beside their combined data .Sowing cotton early would provide cotton plants with comparatively lower accumulated temperature during their early growth stages and helped plants to have at their disposal a longer period for flowering. Therefore, this condition led to an increase in number of fruiting branches, number of open bolls, and boll weight. This consequently increased production of seed cotton yield. Similar results were obtained by Abou ElZahab et al. (2000), El-Fesheikawy (2003) and El-Hindi et al. (2006).

\section{1-B-Nitrogen fertilizer:}

Data in Tables1and 2 revealed that nitrogen fertilizer levels i.e. 50, 70 and $90 \mathrm{Kg} / \mathrm{fed}$. had no significant effect on number of fruiting branches per plant ,plant height, lint percentage, seed index and lint index traits. However the number of open bolls per plant, boll weight, seed cotton yield per plant and per feddan were significantly affected by applying different levels of nitrogen fertilizer .In this regard ,adding $90 \mathrm{Kg} \mathrm{N} / \mathrm{fed}$. was found to give heavier bolls as compared to the treatments of 70 and $50 \mathrm{Kg} \mathrm{N} / \mathrm{fed}$. These results are in agreement with those obtained by Hamissa et al. (2000), Sadik et al. (2002), Ali (2002), and El-Hindi et al. (2006) who indicated that number of open bolls/plant increased as levels of nitrogen fertilizer was raised up to $80 \mathrm{~kg} \mathrm{~N} /$ fed.

\section{1-C-Planting populations:}

Number of fruiting branches per plant, plant height, number of open bolls, boll weight, seed cotton yield per plant and per feddan and lint percentage characters were significantly affected by planting populations. Seed index and lint index were not affected by the various plant densities during the two growing seasons. The increment in plant height could be attributed that in case of higher dense population excessive shade exists which helped to produce more content of gibberellins in tissues and consequently higher plants were produced (Wareing and Philips 1970).

\section{1-D-Interaction effect:}

The results in Tables 1 and 2 show that the three factors interact significantly on most growth and yield characters. The first and second order interactions in each season and the combined data of the two seasons were significant at 5\% level. The illustrated findings indicated that the three variables involved in the study affect significantly in most characters individually and further by acting in combination with each other. Moreover, the combined analysis which showed the same significant interactions, indicating that levels applied from each of sowing dates on the studied traits differed in accordance to the planting populations and in nitrogen fertilizer rates. 
Fayoum J. Agric. Res. \& Dev., Vol.22, No.1, January, 2008 
Fayoum J. Agric. Res. \& Dev., Vol.22, No.1, January, 2008 
Fayoum J. Agric. Res. \& Dev., Vol.22, No.1, January, 2008 
Fayoum J. Agric. Res. \& Dev., Vol.22, No.1, January, 2008 
2-Yield analysis:

The higher yield obtained from applying the treatment combination of $\mathrm{D} 1 \times \mathrm{N} 1 \times \mathrm{P} 1$ was subjected to yield analysis procedures as fallows:

2-A-Simple correlation.

The relationship between yield per plant and each of the eight characters in each season is presented in Table 3 The seed cotton yield per plant had positive and highly significant interrelationships with each of: Number of fruiting branches/plant, number of open bolls/plant, boll weight, lint percentage, seed index and lint index. On the other hand, there was a negative significant correlation coefficient between seed cotton yield/plant and plant height.

Table (3) A matrix of simple correlation coefficient between seed cotton yield per plant and other important characters estimated in each studied season.

\begin{tabular}{|c|c|c|c|c|c|c|c|c|c|}
\hline Characters & $\mathbf{S}$ & $\mathbf{Y}$ & 1 & 2 & 3 & 4 & 5 & 6 & 7 \\
\hline \multirow{2}{*}{$\begin{array}{l}\text { Y-Seed yield } \\
\text { cotton/plant } \\
(\mathrm{SCYP}) \\
\end{array}$} & 2005 & 1.000 & & & & & & & \\
\hline & 2006 & 1.000 & & & & & & & \\
\hline \multirow{2}{*}{$\begin{array}{l}\text { 1-plant height } \\
\text { (PH) }\end{array}$} & 2005 & $-.230^{*}$ & 1.000 & & & & & & \\
\hline & 2006 & $-.392^{* *}$ & 1.000 & & & & & & \\
\hline \multirow{2}{*}{$\begin{array}{l}\text { 2-No. of fruiting } \\
\text { branches/plant } \\
\text { (NFBP) }\end{array}$} & 2005 & $.735^{* *}$ & $.270^{* *}$ & 1.000 & & & & & \\
\hline & 2006 & $.841^{* *}$ & .030 & 1.000 & & & & & \\
\hline \multirow{2}{*}{$\begin{array}{l}\text { 3-No.of open } \\
\text { bolls/plant } \\
\text { (NOBP) }\end{array}$} & 2005 & $.867^{* *}$ & $-.474^{* *}$ & $.378^{* *}$ & 1.000 & & & & \\
\hline & 2006 & $866^{* *}$ & $-.585^{* *}$ & .141 & 1.000 & & & & \\
\hline \multirow[t]{2}{*}{ 4-Boll weight (BW) } & 2005 & $.942^{* *}$ & $.884^{* * *}$ & $.321^{* *}$ & $-.373^{* *}$ & 1.000 & & & \\
\hline & 2006 & $802^{* *}$ & $.859^{* *}$ & $.223^{* *}$ & $-.469^{* *}$ & 1.000 & & & \\
\hline \multirow{2}{*}{$\begin{array}{l}\text { 5-Lint percentage } \\
\text { (L \%) }\end{array}$} & 2005 & $.788^{* *}$ & $-.216^{*}$ & $.678^{* * *}$ & $.592^{* *}$ & -.164 & 1.000 & & \\
\hline & 2006 & $650^{* *}$ & $-.284^{* *}$ & $.831^{* *}$ & $.191^{*}$ & -.122 & 1.000 & & \\
\hline \multirow[t]{2}{*}{ 6-Seed index (SI) } & 2005 & $.729^{* * *}$ & $.755^{* *}$ & $.510^{* * *}$ & -.140 & $.813^{* *}$ & .095 & 1.000 & \\
\hline & 2006 & $601^{* *}$ & $.583^{* *}$ & -.050 & $-.418^{* * *}$ & $.526 * *$ & $-.257^{* *}$ & 1. 000 & \\
\hline \multirow[t]{2}{*}{ 7-Lint index (LI) } & 2005 & $.692^{* *}$ & $.789^{* *}$ & $.234^{*}$ & $-.340^{* * *}$ & $.792^{* *}$ & -.178 & $.751^{* *}$ & 1.000 \\
\hline & 2006 & $673^{* *}$ & $.551^{* *}$ & -.044 & $-.528^{* *}$ & $.562^{* * *}$ & -134 & $.733^{* *}$ & 1.000 \\
\hline
\end{tabular}

$*, * *$ denotes significant at $5 \%$ and $1 \%$ respectively.

\section{2-B-Stepwise multiple regressions analysis:}

The results obtained in Table 4 clarify that three characters i.e. boll weight, number of fruiting branches/plant and number of open bolls/plant were significantly contributing to variation in seed cotton yield/plant in 2005 and 2006 seasons are responsible for reducing $91.8 \%$ and $89.2 \%$ of total yield variance, respectively.

The other characters are removed variables because their contribution in yield variation was very small. They reduced only $0.8 \%$ and $1.8 \%$ of total yield variance in the two seasons, respectively.

Fayoum J. Agric. Res. \& Dev., Vol.22, No.1, January, 2008 
2-C-Path coefficient analysis:

The path coefficient analysis (Table 5) indicated that boll weight, number of fruiting branches/plant and number of open bolls/plant showed the most prominent direct and indirect effects in 2005 and 2006 seasons with highest relative importance values being $26.61 \%, 6.02 \%$ and $1.87 \%$ for thesr traits in the same order Also, the same characters being $13.65 \%, 11.16 \%$ and $5.87 \%$ respectively in 2006 season. This finding is in agreement with those obtained by El- Shaer et al. (1984), Seyam et al. (1984), Ghaly et al. (1990), Abou-Zahara et al. (1992), Badr et al. (1999) and Hassan and Abdel-Aziz (2004), who found that the direct effects of number of open bolls/plant and boll weight as well as their indirect effects were responsible for $91.8 \%$ in the variation of plant yield.

Table (4). Accepted and removed variables according to stepwise analysis and their relative contribution $(\mathbf{R} 2 \%)$ in cotton yield per plant variation during the two growing seasons of 2005 and 2006.

\begin{tabular}{|l|c|c|}
\hline & 2005 & 2006 \\
\hline Prediction equation & $\begin{array}{c}\text { Y }=-84.17+16.66 \mathrm{BW}+1.38 \\
\text { NFBP }+0.45 \mathrm{NOBP}\end{array}$ & $\begin{array}{c}\mathrm{Y}=-\mathbf{5 7 . 2 4}+1.96 \mathrm{BW}+1.39 \\
\text { NFBP }+0.78 \mathrm{NOBP}\end{array}$ \\
\hline $\mathbf{R}^{2}$ for all variables & $\mathbf{9 2 . 6 \%}$ & $\mathbf{9 1 . 0 \%}$ \\
\hline $\begin{array}{l}\text { Acceptance variables } \\
\mathbf{R}^{2} \text { for acceptance } \\
\text { variables }\end{array}$ & $\mathrm{BW}, \mathrm{NFBP}$ and NOBP & BW, NFBP and NOBP \\
\hline Removed variables & $\mathbf{9 1 . 8 \%}$ & $\mathbf{8 9 . 2 \%}$ \\
\hline
\end{tabular}

Table (5). Direct and indirect effects of some important characters and their relative contribution in seed cotton yield per plant during the two growing seasons of 2005 and 2006.

\begin{tabular}{|c|c|c|c|c|c|}
\hline \multirow{2}{*}{\multicolumn{2}{|c|}{ Variables }} & \multicolumn{2}{|c|}{2005} & \multicolumn{2}{|c|}{2006} \\
\hline & & \multirow{2}{*}{$\begin{array}{c}\mathrm{CD}^{*} \\
\mathbf{0 . 0 0 6} \\
\end{array}$} & \multirow{2}{*}{$\begin{aligned} \text { RI \%*** } \\
0.21 \\
\end{aligned}$} & \multirow{2}{*}{$\begin{array}{l}C^{*} \\
0.004 \\
\end{array}$} & \multirow{2}{*}{$\frac{\mathrm{RI} \% * *}{0.18}$} \\
\hline plant height (PH) & $\mathrm{x}_{1}$ & & & & \\
\hline $\begin{array}{l}\text { No. of fruiting branches/plant } \\
\text { (NFBP) }\end{array}$ & $x_{2}$ & 0.075 & 6.02 & 0.283 & 11.16 \\
\hline No. of open bolls/plant (NOBP) & $\mathbf{x}_{3}$ & 0.024 & 1.87 & 0.149 & 5.87 \\
\hline Boll weight (BW) & $x_{4}$ & 0.343 & 26.61 & 0.346 & 13.65 \\
\hline Lint percentage (L \%) & $x_{5}$ & 0.001 & 0.11 & 0.000 & 0.00 \\
\hline Seed index $(\mathrm{SI})$ & $x_{6}$ & 0.002 & 0.19 & 0.006 & 0.22 \\
\hline Lint index (LI) & $\mathrm{x}_{7}$ & 0.002 & 0.13 & 0.002 & 0.09 \\
\hline $\mathrm{X}_{1} / \mathbf{X}_{\mathrm{i}}{ }^{\prime} \mathbf{s}$ & & 0.001 & 0.36 & 0.007 & $\overline{0.34}$ \\
\hline $\mathbf{X}_{2} / \mathbf{x}_{\mathrm{i}}{ }^{\prime} \mathbf{s}$ & & 0.147 & 12.77 & -0.021 & 8.01 \\
\hline $\mathbf{X}_{3} / \mathbf{x}_{\mathbf{i}}{ }^{\prime} \mathbf{s}$ & & 0.044 & 8.66 & -0.122 & 6.24 \\
\hline $\mathbf{X}_{4} / \mathbf{X}_{\mathbf{i}}{ }^{\prime} \mathbf{S}$ & & 0.254 & 23.13 & 0.329 & 35.11 \\
\hline $\mathbf{X}_{5} / \mathbf{X}_{\mathrm{i}}{ }^{\prime} \mathbf{S}$ & & 0.001 & 0.34 & 0.001 & 0.05 \\
\hline $\mathrm{X}_{6} / \mathbf{X}_{\mathrm{i}}{ }^{\prime} \mathbf{S}$ & & -0.003 & 0.23 & 0.004 & 0.14 \\
\hline $\mathbf{X}_{7} / \mathbf{x}_{\mathbf{i}}{ }^{\prime} \mathbf{S}$ & & 0.000 & 0.00 & 0.000 & 0.00 \\
\hline Residual & & 0.070 & 5.78 & 0.097 & 6.28 \\
\hline
\end{tabular}

Multiple coefficient of determination in $2005=94.22 \%$

Multiple coefficient of determination in $2006=\mathbf{9 3 . 7 2 \%}$

$* \mathbf{C D}=$ Coefficient détermination $\quad * * \mathbf{R I}=$ Relative importance.

Fayoum J. Agric. Res. \& Dev., Vol.22, No.1, January, 2008 
The results clarify that boll weight, number of fruiting branches /plant and number of open bolls/plant had the highest indirect effects were $(23.13 \%$, 12.77 and $8.66 \%$ ) in 2005 season, contributing to seed cotton yield/plant variation and the same trend of this result was obtained in the second season. The total contribution of the above mentioned characters over all variation in seed cotton yield/plant in 2005 and 2006 season were $94.22 \%$ and $93.72 \%$, respectively.

The residual effect in seed cotton yield/plant variation in the present investigation was $5.78 \%$ in 2005 season and $6.28 \%$ in 2006 season. It is clear that the residual effect has slight importance and showed very small contribution in seed cotton yield/plant variation. In general the results obtained herein indicated that boll weight and number of open bolls/plant were the major contribut in seed cotton yield/plant variation.

\section{REFERENCES}

Abdel-Aal, H.A.; K.A. Ziadah; A.A. Darwish and W.M.O.El-Shazly (2000). Proper hill spacing and optimum NPK rate for cotton Giza 89. Alex. Sci. Exch., 21 ( 3): pp. 197 - 210.

Abou-El-Zahab, A.A.; Sohair, E.D. Elayan and Samia E.S. Ali (2000). Cotton growth parameters and production of Giza 75 cotton variety as affected by sowing date and N - levels. J. Agric. Sci. Mansoura Univ., 25 (12): 7367 - 7379.

Abou-Zahra, S. I. S.; Awaad, M. M. and Foraisa, A. Al-Enani (1992). Determining characters contribution to seed cotton yield in some intervarietal and inter specific lines using stepwise regression analysis. Annals of Agric. Sci. Moshtohor . 30 (2): 645 - 652.

Ali, S.A. (2002). Response of cotton cultivar Giza 85 to irrigation intervals and N- levels. J. Agric Sci. Mansoura Univ., 27(1): 117 - 127.

Ali, S.A. and A. E. El-Sayed (2001a). Response of cotton cultivar Giza 70 to ((Mepiquat Chloride) pix at early and late sowing dates. J. Agric. Sci. Mansoura Univ., 26 (4): 1841 - 1851.

Ali, S.A. and A. E. El-Sayed (2001b). Effect of sowing dates and nitrogen levels on growth, earliness and yield of Egyptian cotton cultivar Giza 88. Egypt .J. Agric. Res., 79 (1): 221 - 232.

Badr, S.S.M.; H.A. El-Harony and. A.E. Ayoub (1999). The correlation and path coefficient analysis of yield components to lint yield in eight Egyptian cotton varieties. J. Agric. Sci. Mansoura Univ., 24 (1): 141 153.

Badr, S.S.M.; I.S.M. Hassan and Laila, M.A.Abdel-Rahman (2001). Comparative study on flowering, yield components and lint properties of some new Egyptian cotton cultivar. J. Agric. Sci. Mansoura , 26 (6): 3473 - 3486.

Draper, N. R. and H. Smith (1966). Applied regression analysis. John Willey and Sons. Inc, New York - 407 PP.

El-Fesheikawy, A.B.E. (2003). Effect of some environmental conditions on yield, seed and fiber quality of some Egyptian cotton cultivars. M. SC. These, Fac. Agric Minia Univ.

Fayoum J. Agric. Res. \& Dev., Vol.22, No.1, January, 2008 
El-Hindi, M.H.; E.M. Said; M.H. Ghonema and A.E. Khalifa (2006). Studies on the effect of some cultural practices on the growth and the yield of Egyptian cotton. J. Agric. Sci. Mansoura Univ., 31 (7): 4087 $-4095$.

El-Sayed, E.A. and M. El-Menshawi (2005a). Response of the promising hybrid cotton Giza $89 \times 86$ to hill spacing and nitrogen fertilizer levels. J. Agric. Res. Tanta, 31 (3): 436 - 456.

El-Shahawy, M.I. and R.R. Abdel-Malik (2000). Response of Giza 87 cotton cultivar to mepiquat chloride (pix) and nitrogen levels. Egypt. J. Agric. Res., 78 (2): 769 - 780.

El-Shear;M. R. Shabana; A.H. El-Shiekh, and Laila, M.A. abdel-Rahman (1984). Path coefficient analysis of some characters contribution to yield and quality of cotton Agric. Res. Rev. 62 (6): 23 - 31.

El-Shazly, W.M.O. and A.A. Darwish (2001). Response of yield cotton (Giza 89 cultivar) to nitrogen levels and biofertilization with microbin. Minufiya J. Agric. Res. 26 (3): 635 - 658.

El-Shazly, W M.O. and M.F. EI-Masri (2002). A comparative study on the effect of some organic manures and Mineral nitrogen fertilizer on the leaf chemical composition, growth, earliness and yield of cotton (Giza 89 cultivar). Minufiya J. Agric. Res. 27 (6): 1325 - 1348.

Fritschi, F.B.; B.A.Roberts; R.L.Travis; D.W. Rains and R.B. Hutmacher (2003). Response of irrigated Acala and Pima cotton to nitrogen fertilization: growth, dry matter partitioning, and yield. Agron. J. 95: $133-146$.

Ghaly, F.; M.Thnan, M. El-Gamal, M.H. El-Banna and Samia, D. Antoun (1990). Path coefficient analysis of some characters contribution using to yield variation of Giza 77 cotton cultivar. Agric. Res. Rev., 68(6): 1101-1109.

Hamissa, A.M.; K.A. Ziadah, and M. F. El-Masri (2000). Response of cotton to biofertilizer and nitrogen fertilization. Minufiya J. Agric. Res. 25 ( 2): 371 - 388.

Hassan, I.S.M. and A.M. Abdel- Aziz (2004). Multivariate analysis of yield and relative contribution of variables to variation in cotton yield. $\mathrm{J}$. Agric. Sci. Mansoura Univ., 29 (10): 5467 - 5473.

James, J.M.; D.L. Wright; P.J. Wiatrak and M.A.Vagas (2004). Effect of row width and nitrogen on cotton Morphology and canopy microclimate. Crop Sci.44: 870 - 877.

Sadik, F.A.; S.M. El-Sadany and M.S.M. Baza (2002). Response of cotton crop to varying levels of $\mathrm{N}$ and $\mathrm{K}$ fertilizer. Egypt. J. Appl. Sci., 17 (6): 390 - 399.

Saleh, M.E.; S.A. I. Ghanem; O.A.A. Zeiton and G.i.M.A. Rashed (2004). Effect of planting date, density and nitrogen fertilization on shedding, earliness, yield and fiber quality of Egyptian cotton. Zagazig. J. Agric. Res., 31 (6): 2597 - 2620.

Seyam, S.M.; A.A. Abo El-Zahab; H.N. El-Rassas, and F.M. El-Rayse (1984). The use of stepwise regression analysis in determining characters for yield selection in Egyptian cotton. Agric. Res. Rev. 62 (6) 41 - 47.

Snedecor, G.A. and A.D. Cochran (1981). Statistical methods 7th Edition, Iowa State Univ.

Fayoum J. Agric. Res. \& Dev., Vol.22, No.1, January, 2008 
Vacek, S.G.; J.E. Matocha; J.R. Smart; P. Dugger and D. Richter (2000). Effect of population, row spacing and nitrogen fertilization on lint yields of no-till cotton. Proc. Beltwide Cotton Conf, San Antonio, U.S.A. 4-8 January 2000, 2: 1416 - 1419.

Wareing, R.E. and I.D.G. Philips (1970). The control of growth and differentiation in plants. Program Press Ltd., Heading ton, Hill gall, Oxford, S.A., 303 pp.

$$
\begin{aligned}
& \text { دراسة اسهام بعض العوامل الزراعية في اختلاف محصول القطن } \\
& \text { سمير كامل على اسماعيل ، محمد دسوقى حسن دويدار ، فاروق محمد اسماعيل }
\end{aligned}
$$

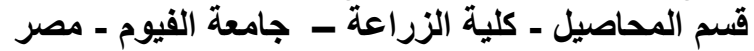

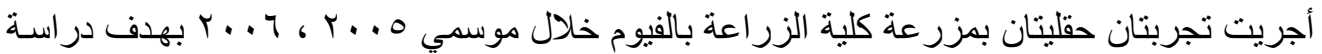

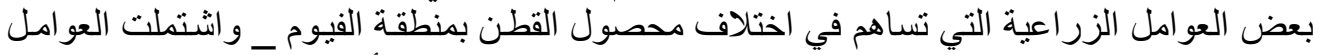

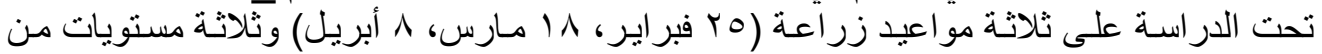

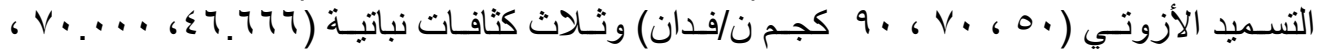

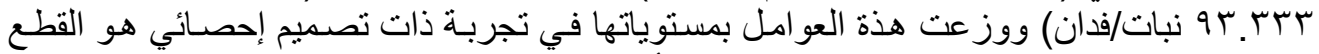

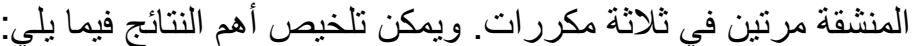

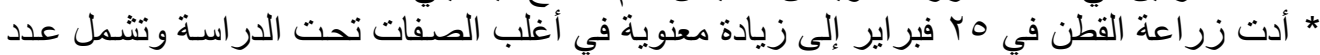

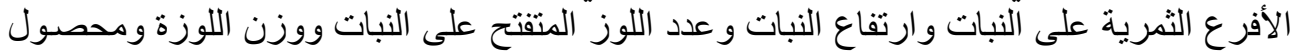

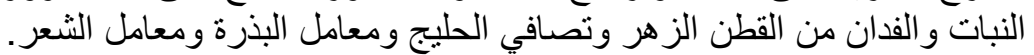

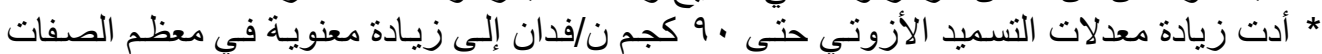

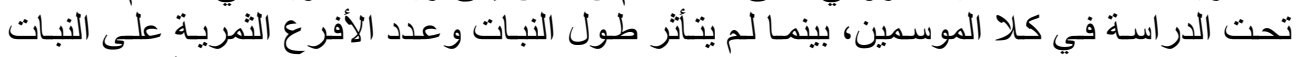
وتصافي الحليج ومعامل البذرة ومعامل الثـعر بالمستويات المستخدمة من التسميد الأزوتي خـالال

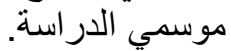

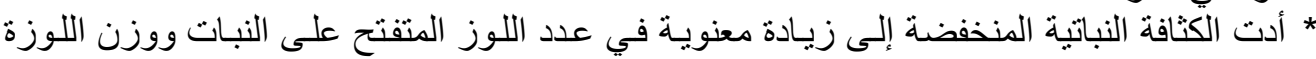

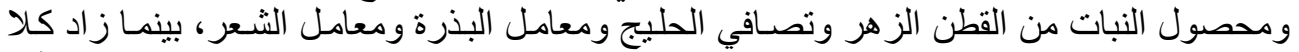

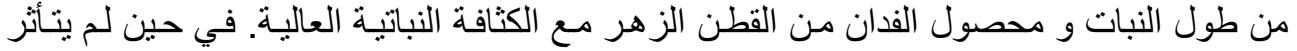

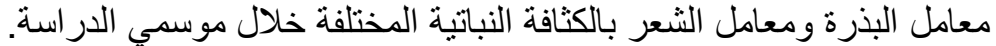
أدى التفاعل بين العو امل تحت الدر اسة بمستوياتها المطبقة إلى زيادة معنويـة في كل الصفات الصفات

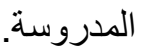
كمـا وجد أن ميعـاد الزر اعـة المبكر والكثافـة النباتيـة المنخفضــة ومعدل التسميد العـالي هي

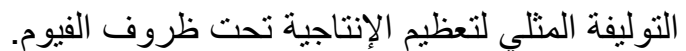

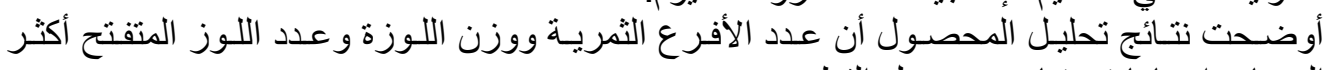
الصفات إسهاما في تباين محصول القطن. 